риал и диаметр зажимов так, чтобы их температура была одинакова и лишь немногим меньше температуры образца. Оба зажима должны иметь малую и, по возможности, одинаковую постоянную времени, чтобы при внезапных изменениях температуры не нарушилось однородное распределение температуры вдоль образца.

При соблюдении упомянутых условий температура будет по всей длине образца практически постоянной.

\title{
ЗАКЛІОЧЕНИЕ
}

Было показано, что сравнительно простыми средствами можно построить. маятник тручения для измерения трения неферромагнитных металлов. при повыпенных температурах. Его преимуществом является малая тепловая инерция, поэтому он удобен для исследований старения легких сплавов. Открытым остается вопрос о поддерживании постоянства температуры при температурах значительно превышающих диапазон температур, применяемых при исследовании старения легких сплавов.

В заключение благодарю Я. Беднаржа за критические заметки к работе.

Поступило 3. 10. 1957.

\section{TORSIONAL PENDULUM WITH SMALL TIME CONSTANT}

(Abstract of preceding paper)

KARET MíšseK

Institute of Technical Physics, Czechosl. Acad. Sci., Prague

A torsional pendulum, in which a sample $1 \mathrm{~mm}$ in diameter is heated by an electric current passing throught it, was set up on the principle described earlier [1]. The current is led through the upper fixed clamp and mercury contact (see Fig. 1). The temperature of the sample is measured with a chromium-nickel/constantan thermo-couple; each of the wires of the thermo-couple $(\varnothing 0.10 \mathrm{~mm})$ is electrolytically tapered at the end and then pulled through an opening $0.05 \mathrm{~mm}$ in diameter, drilled in the wire. After being pulled through small balls are soldered onto the ends of the thermo-couple wires to prevent the latter being pulled out of the openings (Fig. 2). The contact between the wires is relatively stable and can be renewed by the passage of an electric current.

Relation. (6) between the temperature $t_{n}$ in the axis of the sample and the temperature on the surface $t$ is derived by a simple calculation. For aluminium (max. current passing through is $40 \mathrm{~A}$ ) this difference in temperature is negligible (smaller than $0.1^{\circ} \mathrm{C}$ ). A relation (9) is also derived for the ratio of the temperatures $t_{0} / t_{v}$, expressed by means of the basic thermal constants.

In another section it is shown that a decrease in the eross-section of the rod produced. by drilling openings causes a negligible increase in temperature (14).

The time constant on heating is approximately given by relation (18), and for cooling by ralation (21).

In conclusion a discussion is given of the conditions under which the sample has constant temperature practically throughout its length.

Received 3. 10. 1957.

$$
\text { Jumeparnypa - References }
$$

[1] Ang C., Wert C.: A Torsional Pendulum of Low Thermal Tnertia, J. Appl. Phys. 25 (1954), 1061

[2] Kề T. ६.: Phys. Rev. 71 (1947), 533.

[3] Михеев М. А.: „Основы теплопередачи“, Госәнергоиздат, Москва-Ленинград, 1949,344 